\title{
Habitat suitability of cetaceans in the Gulf of Mexico using an ecological niche modeling approach
}

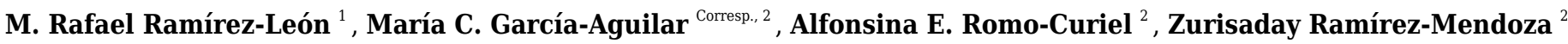 \\ , Arturo Fajardo-Yamamoto ${ }^{2}$, Oscar Sosa-Nishizaki ${ }^{2}$ \\ 1 Posgrado en Ecología Marina, Centro de Investigación Científica y de Educación Superior de Ensenada, Baja California, Ensenada, Baja California, Mexico \\ 2 Departamento de Oceanología Biológica, Centro de Investigación Científica y de Educación Superior de Ensenada, Baja California, Ensenada, Baja \\ California, Mexico
}

Corresponding Author: María C. García-Aguilar

Email address: gaguilar@cicese.mx

Background. The Gulf of Mexico (GOM) is a semi-enclosed sea where the waters of the United States, Mexico and Cuba converge. Al least 21 species of cetaceans inhabit it. The only mysticete (baleen whale) is found in the northeast (U.S. waters). The distribution of the 20 species of odontocetes (toothed cetaceans) is well understood in U.S. waters, but practically unknown in Mexican and Cuban waters. In this study we used sighting data from several odontocete species to construct habitat suitability maps in order to identify geographical regions suitable for high diversity throughout the GOM. Methods. Historical datasets of georeferenced sightings from across the GOM were used to implement the maximum entropy algorithm (MaxEnt) to model the habitat suitability of each species. Five environmental predictors were used, selected for their influence over the occurrence of cetaceans: two oceanographic predictors (sea surface temperature and chlorophyll-a concentration), and three bathymetric predictors (depth, slope, and distance to 200-m isobath). A spatial approach based on the habitat suitability maps was used to identify the suitable regions. Results. Only 12 species were modeled, which were the ones with the minimum sample size required. The models performed well, showing good discriminatory power and slight overfitting. Overall, depth, minimum sea surface temperature, and bottom slope were the most contributing predictor in the models. High suitability areas of 10 species were located on the continental slope, and four suitable regions were identified: (1) the Mississippi Canyon and the Louisiana-Texas slope in the northern GOM, (2) the west Florida slope in the east-northeastern GOM, (3) the Rio Grande slope in the westnorthwestern GOM, and (4) Tamaulipas-Veracruz in the west-southwestern GOM. 


\section{Habitat suitability of cetaceans in the Gulf of Mexico using}

\section{2 an ecological niche modeling approach.}

3 M. Rafael Ramírez-León ${ }^{1}$, María C. García-Aguilar ${ }^{2}$, Alfonsina E. Romo-Curiel ${ }^{2}$, Zurisaday

4 Ramírez-Mendoza ${ }^{2}$, Arturo Fajardo-Yamamoto ${ }^{2}$, Oscar Sosa Nishizaki ${ }^{2}$

5

6 Posgrado en Ecología Marina, Centro de Investigación Científica y de Educación Superior de

7 Ensenada, Baja California, Ensenada, Baja California, Mexico.

8

9 2Departamento de Oceanología Biológica, Centro de Investigación Científica y de Educación

10 Superior de Ensenada, Baja California, Ensenada, Baja California, Mexico.

12 Corresponding Author:

13 María C. García-Aguilar

14 Carretera Ensenada-Tijuana No 3918, Ensenada, Baja California, 22860, Mexico.

15 Email address: gaguilar@cicese.mx 
16

17

18

\section{Abstract}

Background. The Gulf of Mexico (GOM) is a semi-enclosed sea where the waters of the United States, Mexico and Cuba converge. Al least 21 species of cetaceans inhabit it. The only mysticete (baleen whale) is found in the northeast (U.S. waters). The distribution of the 20 species of odontocetes (toothed cetaceans) is well understood in U.S. waters, but practically unknown in Mexican and Cuban waters. In this study we used sighting data from several odontocete species to construct habitat suitability maps in order to identify geographical regions suitable for high diversity throughout the GOM.

Methods. Historical datasets of georeferenced sightings from across the GOM were used to implement the maximum entropy algorithm (MaxEnt) to model the habitat suitability of each species. Five environmental predictors were used, selected for their influence over the occurrence of cetaceans: two oceanographic predictors (sea surface temperature and chlorophyll$a$ concentration), and three bathymetric predictors (depth, slope, and distance to 200-m isobath). A spatial approach based on the habitat suitability maps was used to identify the suitable regions. Results. Only 12 species were modeled, which were the ones with the minimum sample size required. The models performed well, showing good discriminatory power and slight overfitting. Overall, depth, minimum sea surface temperature, and bottom slope were the most contributing predictor in the models. High suitability areas of 10 species were located on the continental slope, and four suitable regions were identified: (1) the Mississippi Canyon and the LouisianaTexas slope in the northern GOM, (2) the west Florida slope in the east-northeastern GOM, (3) the Rio Grande slope in the west-northwestern GOM, and (4) Tamaulipas-Veracruz in the westsouthwestern GOM. 
38 Conclusions. We were able to detect four geographic regions in the GOM where a high diversity

39 of odontocetes is expected, all located on the continental slope. Although the methodology to

40 identify them (spatial overlap) is a very conservative approach, it is useful for conservation and

41 management purposes. The paucity of data did not allow all species to be modeled, which

42 highlights the importance of establishing transboundary monitoring programs.

Keywords: Odontocetes, species distribution, MaxEnt, segregated distribution.

\section{Introduction}

Understanding species' geographic distribution patterns and related environmental factors is a central topic of population ecology (Guisan \& Zimmermann, 2000). Environmental factors include both abiotic conditions that influence the physiological response (e.g., temperature) determined in turn by the species' adaptive responses and the interspecific interactions (e.g., prey availability) (Soberón \& Peterson, 2005; Peterson et al., 2011). Cetaceans are a group of fully aquatic mammals whose anatomical, morphological and physiological adaptations have allowed them to colonize a wide variety of aquatic habitats (Katona \& Whitehead, 1988). Nevertheless, their distribution is usually explained in terms of the abundance of prey, primarily controlled by dynamic oceanographic conditions (e.g., sea surface temperature and mesoscale processes), as well as by physiographic features (e.g., bottoms depth and slope) (Kenney et al., 1997; Forcada, 57 2018).

$$
\text { The Gulf of Mexico (GOM) is a semi-enclosed sea connected to the Atlantic Ocean and }
$$


61 ( 40\%), and Cuba ( 5\%) (De Lanza Espino \& Gómez-Rojas, 2004). There are at least 21 species

62 of cetaceans that inhabit the GOM, including one mysticete, the Bryde's whale (Balaenoptera

63 edeni), which is distributed exclusively in the northeastern GOM (Soldevilla et al., 2017), and

6420 odontocetes (Würsig, 2017).

65 The distribution of cetaceans in the northern GOM (i.e., the U.S. EEZ) has been extensively

66 studied. Based on sighting records, Maze-Foley \& Mullin (2006) divided the cetaceans into two

67 communities: (1) the continental shelf community, which includes the bottlenose dolphin

68 (Tursiops truncatus), the Atlantic spotted dolphin (Stenella frontalis), and the Bryde's whale, and

69 (2) the continental slope community, which comprises the remaining species, although the

70 rough-toothed dolphin (Steno bredanensis) can be found in both. More recently, Roberts et al.

71 (2016) used density surface models to describe the spatial distribution of cetaceans in the

northern GOM. Overall, their results are consistent with those of Maze-Foley \& Mullin (2006),

although they highlight the importance of the continental slope and submarine canyons, such as

the Mississippi Canyon, as areas of high density of cetaceans. In contrast, the distribution of cetaceans in the southern GOM (i.e., the EEZs of Mexico and Cuba) is poorly understood. In fact, only one study has covered this region, but it was conducted by extrapolating data from the northern GOM (Mannocci et al., 2017).

Besides the ecological relevance of the GOM, it is an important economic area where fishing, tourism, and the hydrocarbon industry generate billions of dollars annually (Karnauskas et al., 2013), and it is a key transportation region (Shepard et al., 2013). Given its economic importance, the GOM ecosystem is under increasing anthropogenic pressure, threatening cetacean populations (Roberts et al., 2016). To determine the extent and impact of these hazards and to optimize threat mitigation and conservation measures, it is necessary to have accurate 
84 predictions of their distribution on a broader scale; that is, at the ecosystem level. However, the

85 latter is complicated given the limited data on cetaceans in the southern GOM (Ramírez-León et

86 al., 2020), but one way to achieve this is to use ecological niche models (ENM).

87 ENM are statistical tools that define the distribution of suitable habitats of a species based on

88 its ecological requirements (Peterson et al., 2011). The rationale is that the records, which are

89 discontinuous in nature, are related to environmental and/or spatial characteristics

90 (environmental predictors) to predict the suitable areas of the species in unsampled locations;

91 therefore, the maps produced are spatially continuous, showing the regions where greater

92 aggregation is expected (Franklin, 2010). Thus, areas of high habitat suitability are defined as

93 those sites were ideal (or favorable) conditions exist for a species' long-term subsistence

94 (Peterson \& Soberón, 2012).

95 Our objective was to estimate the habitat suitability of the odontocetes of the GOM to

96 identify those geographical regions that could support a high diversity of these cetaceans. The

97 analysis included historical datasets of georeferenced sightings (presence-only data) recorded in

98 both the south and north of the GOM. We used the maximum entropy (MaxEnt) modeling

99 approach (Phillips, Anderson \& Schapire, 2006), and five environmental predictors were selected

100 based on their documented importance in determining the occurrence of cetaceans, either directly

101 or indirectly: sea surface temperature, chlorophyll- $a$ concentration, bottom depth and slope, and

102 distance to the 200-m isobath (e.g., Praca et al., 2009; Fernandez et al., 2018; Pace et al., 2018).

103

104 Materials and Methods

105 Study and modeling area 
106 The modeling area was not restricted to the GOM, due to the high movement capacity of

107 cetaceans, and because there are no physicals barriers in the marine environment for them. The

108 area was extended to include the warm-temperate and tropical oceanic provinces of the

109 northwest Atlantic Ocean (Fig. 1a; Spalding et al., 2007).

110 The physiography of the GOM is complex and consists of 13 physiographic sub-provinces

111 (Fig 1b). The continental shelf $(\leq 200 \mathrm{~m}$ deep) can be very narrow, as the Tamaulipas-Veracruz

112 shelf, or extensive, like the Yucatan and Florida shelves. The continental slope extends from the

$113200 \mathrm{~m}$ continental shelf break to $2,800 \mathrm{~m}$ depth, and there are vast canyons, such as the

114 Mississippi Canyon. The oceanic zone extends beyond the slope up to the abyssal plain, where

115 depths > 3,500 m are reached (Bouma \& Roberts, 1990; Monreal-Gómez, Salas-de León \&

116 Velasco-Méndoza, 2004). The GOM oceanic waters have oligotrophic conditions that contrast

117 with the eutrophic coastal regions, which receive a high nutrient input by river discharges,

118 mainly in the northern GOM (Biggs, 1992; Lohrenz et al., 1999; Muller-Karger et al., 2015).

\section{Presence-only data}

121 Historical georeferenced sightings (presence-only data) of odontocetes were compiled. We

122 discarded the Blainville's beaked whale (Mesoplodon densirostris), Gervais's beaked whale (M.

123 europaeus), killer whale (Orcinus orca), and Fraser's dolphin (Lagenodelphis hosei) from our

124 study because sightings of these species are infrequent (Würsig, 2017). The presence-only data

125 of the remaining 16 species (Table 1; Supplemental Data S1) were collected from the literature

126 (e.g., peer-reviewed articles, thesis, and technical reports), and digital databases of the Sistema

127 Nacional de Información Sobre la Biodiversidad (SNIB; http://www.snib.mx/; CONABIO, 2016)

128 and Ocean Biogeographic Information System Spatial Ecological Analysis of Megavertebrate 
129 Populations (OBIS-SEAMAP; http://seamap.env.duke.edu/; Halpin et al., 2006). To reduce the

130 sampling bias (the north of the GOM is oversampled relative to the south) and the spatial

131 autocorrelation that negatively affects model performance (Boria et al., 2014; Varela et al.,

132 2014), we filtered our databases (one per species) using the spThin package (Aiello-Lammens et

133 al., 2015) in R software (R Core Team, 2019). The thin function uses a random approach to

134 return a dataset with the maximum number of records for a given distance restriction, which in

135 this study it was defined by the average daily displacement of each species (Table 1;

136 Supplemental Information S2).

137

138

139

140

141

142

143

144

145

146

147

148

149

150

151

\section{Environmental predictors}

Five environmental predictors were selected based on previous knowledge about the

environmental factors that influence the cetaceans' occurrence (e.g., Praca et al., 2009; Fernandez

et al., 2018; Pace et al., 2018). The selected predictors included both oceanographic and

bathymetric variables. Used oceanographic predictors were the sea surface temperature (SST,

${ }^{\circ} \mathrm{C}$ ) and chlorophyll- $a$ concentration $\left(\mathrm{Chl}-a, \mathrm{mg} / \mathrm{m}^{3}\right)$, included in three metrics: mean, minimum,

and maximum. Data of both variables were downloaded from the Ocean Color portal

(https://oceancolor.gsfc.nasa.gov/; NASA, 2018) of the MODIS-Aqua sensor for the period July

2002 -December 2018. The data are at an L3 processing level with a spatial resolution of $0.041^{\circ}$

( 4 km). Weekly values (8-d composite) were downloaded and averaged across the 16 years

with available data. Bathymetric predictors were depth $(D, \mathrm{~m})$, bottom slope $(S$, degrees), and

distance to the 200-m isobath $\left(D_{200}, \mathrm{~m}\right)$. The first was acquired from the General Bathymetric

Chart of the Ocean (GEBCO; https://www.gebco.net/; IOC \& IHO, 2018) with a spatial

resolution of $0.008^{\circ}(\sim 1 \mathrm{~km})$; the other two were calculated from the depth using the raster 
152 package (Hijmans et al., 2013) in R software. These bathymetric predictors were re-projected at 153 a spatial resolution of $0.041^{\circ}$.

154 The co-linearity among environmental predictors was evaluated using the Pearson correlation 155 coefficient ( $\rho$ ) (Dormann et al., 2012; Cruz-Cárdenas et al., 2014). If $\rho \geq 0.70$ (Dormann et al.,

156 2013), a principal component analysis was performed (Supplemental Information S3) to

157 determine which of the correlated predictors should be discarded.

\section{Habitat suitability modeling}

160 We used the MaxEnt algorithm (Phillips, Anderson \& Schapire, 2006) to predict the habitat 161 suitability of odontocetes in the GOM. MaxEnt assumes that the species are distributed

162 uniformly (i.e., the maximum entropy distribution) on the modeling area, and the environmental 163 values constrain this distribution at the presence of records locations (Phillips, Anderson \& 164 Schapire, 2006; Phillips et al., 2017). The habitat suitability modeling for each species was conducted using the ENMeval package (Muscarella et al., 2014, 2016) in R. We built models with a random sample of 10,000 background points (i.e., points not registered as occurrence records in the modeling area that are contrasted with the occurrence positions) and select the Linear, Quadratic, and Hinge features of the MaxEnt algorithm. The cross-validation of the models was done using the block method that splits the presence data into four bins, three as training data and one as test data, based on the latitude and longitude lines that divided the

171 occurrence localities (Muscarella et al., 2014).

172 The performance of each model was evaluated using the area under the receiver-operator 173 curve (AUC), which measures the discriminatory ability of each model, and the omission rate 174 (OR), which indicates the proportion of test localities that fall into cells not predicted as suitable 
175 (Philips, Anderson \& Schapire, 2006). An AUC of 1 indicates perfect discrimination between

176 sites where the species is present or absent, and an AUC $<0.5$ indicates that the model

177 performance is less than a random assumption (Elith et al., 2006). We used the 10-percentile

178 training omission rate $\left(\mathrm{OR}_{10}\right)$ because it is less sensitive to the outlier presence locations

179 (Radosavljevic \& Anderson, 2014). Omission rates greater than the expected value of 0.1 (or

180 10\%) suggest model overfitting (Peterson et al., 2011; Radosavljevic \& Anderson, 2014).

181 Finally, we used the contribution percentages returned by each MaxEnt model to evaluate the

182 contribution of each environmental predictor (Phillips, Anderson \& Schapire, 2006).

183 We selected the logistic output and obtained the habitat suitability for each $0.041^{\circ} \times 0.041^{\circ}$

184 cell of the modeling area, which was expressed in an interval between 0 (unsuitable conditions)

185 and 1 (highly suitable conditions). In this study, high suitability areas were defined as those sites

186 (cells) with suitability values $\geq 0.6$ (Kaschner et al., 2011). A spatial approach based on the

187 habitat suitability maps was used to identify suitable regions for cetaceans; that is, regions

188 capable of supporting a high diversity of cetaceans (i.e., suitable regions) were defined as regions 189 where the high suitability areas of at least seven species overlap.

\section{Results}

192

193

194

196
Habitat suitability was modeled for only twelve species (Table 1), which were those that after filtering had the minimum sample required ( $\geq 30$ presence records; Wisz et al., 2008). The pygmy sperm whale (Kogia breviceps), pygmy killer whale (Feresa attenuata), false killer whale (Pseudorca crassidens), and melon-head whale (Peponocephala electra) were excluded due to small sample size (Table 1).

PeerJ reviewing PDF | (2020:07:50756:2:0:NEW 24 Dec 2020) 
The models showed a good degree of discriminatory ability based on the AUC scores, which

198 ranged from 0.74 (the pantropical spotted dolphin, Stenella attenuata, model) to 0.91 (the bottlenose dolphin model) (Table 2). On the other hand, the $\mathrm{OR}_{10}$ value was close to the expected value in some models, such as the rough-toothed dolphin, but in others it was higher, as in the spinner dolphin (Stenella longirostris) model (Table 2), suggesting some degree of overfitting.

The environmental predictors used in each model differ (Table 2; Supplemental Information S4). The bottlenose dolphin models had the fewest predictors, while the Risso's dolphin (Grampus griseus), Atlantic spotted dolphin, pantropical spotted dolphin and spinner dolphin models had the most. Slope was included in 11 models, while both depth and minimum-SST in 10 (Table 2). However, in terms of contribution, depth was the most important environmental predictor, with a contribution of $>25 \%$ in seven models, followed by the minimum-SST, which had an important contribution in five models.

High suitability areas for 10 species were located on the continental slope (Figs. 2-4). The pantropical spotted dolphin seems to be the species with the widest distribution, potentially occupying the entire continental slope. High suitability areas for the sperm whale (Physeter macrocephalus), short-finned pilot whale (Globicephala macrorhynchus), and spinner dolphin were found on the inner continental slope, while for the rough-toothed dolphin they were located both on the outer continental shelf and on the slope. Dwarf sperm whale (Kogia sima), Risso's dolphin, and Cuvier's beaked whale (Ziphius cavirostris) models show almost continuous high suitability along the northern continental slope, from Florida to Louisiana-Texas, even extending to the Rio Grande and Tamaulipas-Veracruz slopes. High suitability areas for the Clymene dolphin (Stenella clymene) were found on the northern slope, with small patches on the Tamaulipas-Veracruz slope. Striped dolphin (Stenella coeruleoalba) model identified as high 
220 suitability areas some patches on the Tamaulipas-Veracruz slope and on the bay of Campeche.

221 The Atlantic spotted dolphin model indicates that high suitability areas are located from the

222 continental shelf to the inner slope of the entire GOM, whereas the model of the bottlenose

223 dolphin points to the continental shelf, from Florida to the Tamaulipas-Veracruz.

224 The main region of high diversity of odontocetes was located between the Mississippi Canyon

225 and the Louisiana-Texas slope (Fig. 5). Other suitable regions were identified on the west Florida

226 slope and on the western continental slope, between the Rio Grande and Tamaulipas-Veracruz

227 slopes

228

229 Discussion

230 ENM are powerful tools for generating spatially explicit maps of species' habitat suitability. We

231 used the MaxEnt approach to model the habitat suitability of the GOM odontocetes, using data

232 from both the north and south, and managed to identify regions where high diversity can be

233 expected. We decided to use this approach because it allows the development of reliable models

234 of the potential distribution based on presence-only data, although it is important to emphasize

235 that these models do not represent the probability of the presence of a species. However, due to

236 the paucity of data, we were able to model only 12 of the 20 species present in the GOM.

237 Furthermore, because we use historical sighting records, the resulting maps are integrated images

238 that show no temporal variations, and no biotic interaction were considered. Biotic interactions

239 might improve habitat suitability models, however, require abundance demographic data at

240 population over time (Anderson, 2017).

241 All models had a good discrimination power, with AUC values $>0.70$, indicating that the

242 results are reliable, and can be used in planning management and conservation measures (Elith et 
243 al., 2006; Raes \& Aguirre-Gutiérrez, 2018). On the other hand, the $\mathrm{OR}_{10}$ values were higher than

244 the expected value; however, they are within the range reported in other studies (e.g., Kramer-

245 Schadt et al., 2013; Arthur, Morrison \& Morey, 2019). High OR 10 values suggest overfitting,

246 which could be due to sampling bias and/or noise in the presence data (Anderson \& Gonzalez,

247 2011; Merow et al., 2014). In our study area, the south of the GOM is under-sampled compared

248 to the north. We attempted to reduce this bias using the spatial filtering to minimize the omission

249 error, but it may not have been completely successful, especially in the case of the spinner

250 dolphin model.

251 Among the used environmental predictors, depth was the most important, followed by

252 minimum SST and bottom slope. These results are not surprising since it is well known that

253 these variables influence the occurrence of cetaceans directly; for example, some species display

254 relatively persistent bathymetric associations (Yen, Sydeman \& Hyrenbach, 2004; Harvey et al.,

255 2017), but mainly indirectly by playing a determining role in the availability, distribution, and

256 abundance of their prey (Davis et al., 2002; MacLeod, 2009; Forcada, 2018). In fact, previous

257 studies have shown that the distribution of several species of cetaceans of the GOM is strongly

258 related to depth (e.g., Baumgartner, 1997; Davis et al., 1998; Baumgartner et al., 2001).

259 Our results are consistent with the segregated distribution of cetaceans proposed by Maze-

260 Foley \& Mullin (2006) for the northern GOM. The two dolphin species of the shelf community,

261 the Atlantic spotted dolphins and the bottlenose dolphins, use different habitats. High suitability

262 areas of the Atlantic spotted dolphins were located on the outer continental shelf and the inner

263 slope, while the bottlenose dolphin has coastal habitats, occupying shallower waters; actually, it

264 is the only species that inhabits lagoons, estuaries, and bays (e.g., Mullin et al., 1990; Griffin \&

265 Griffin, 2003; Martínez-Serrano et al., 2011). The continental slope community is composed of 
266 the remaining species (Maze-Foley \& Mullin, 2006; present study), although densities of these

267 can vary seasonally, at least in the northern GOM (Roberts et al., 2016; Mannocci et al., 2017).

268 The aggregation of multiple species reveals important biological regions capable of supporting a

269 high cetacean diversity (Harvey et al., 2017). Ten of the 12 species modeled showed habitat

270 suitability areas along the continental slope, consistent with the relatively high diversity of

271 cetaceans observed on the northern GOM continental slope (Davis et al., 2002; Maze-Foley \&

272 Mullin, 2006; Roberts et al., 2016). The exploitation of different types of habitat and prey allows

273 this co-existence (Bearzi, 2005; Schick et al., 2011). The continental slope of the GOM covers a

274 large area and presents underwater canyons (Bouma \& Roberts, 1990), where the main prey

275 (e.g., cephalopods) of the deep-diving species can accumulate (Biggs, Leben \& Ortega-Ortiz,

276 2000; O'Hern \& Biggs, 2009; Moors-Murphy, 2014). On the other hand, the species that

277 primarily feed on epipelagic prey preferentially use the upper layers of the water column, where

278 mesoscale structures occur (Davis et al., 1998, 2002).

279 We identify four suitable regions. The most notable was located in the north, encompassing

280 the Mississippi Canyon and the Louisiana-Texas slopes, consistent with that previously reported

281 for the north of the GOM (e.g., Mullin \& Fulling, 2006; Roberts et al., 2016). The other regions

282 were located on the west Florida slope (east-northeast of the GOM), the Rio Grande slope (west-

283 northwestern of the GOM), and the Tamaulipas-Veracruz slope (west-southwestern of the

284 GOM). All these regions are characterized by their high primary productivity. In the north,

285 productivity is directly influenced by the input of nutrients from the Mississippi and Atchafalaya

286 rivers (Lohrenz et al., 1999), while in the west by the Grande and Pánuco rivers (Salmerón-

287 García et al., 2011). The plumes of nutrient-rich waters are transported through the continental

288 shelf (Del Castillo et al., 2001; Morey et al., 2003; Zavala-Hidalgo, Morey \& O'Brien, 2003), 
289 reaching the slope by the interactions of anticyclonic-cyclonic eddies (Toner, 2003; Martínez-

290 López \& Zavala-Hidalgo, 2009). However, the largest region suitable for cetaceans was located

291 in the north for two possible reasons. First, the large nutrient input from the Mississippi River

292 into the shelf ecosystem favors huge phytoplankton blooms on spatial scales of tens to hundreds

293 of kilometers (Lohrenz et al., 1997). Second, the continental slope in this region is extremely

294 wide, which could favor the convergence of a greater number of cetacean species.

295

296 Conclusions

297 We identified areas of high suitability for 12 species of odontocetes in the GOM through the 298 implementation of an ENM. Unfortunately, the paucity of data did not allow modeling all the 299 species, which highlights the importance to establish transboundary research and monitoring 300 programs between the U.S., Cuba, and Mexico to improve knowledge on the cetaceans of the 301 GOM. Even so, we were able to detect four geographic regions where a high diversity of 302 odontocetes is expected, all located on the continental slope. These suitable regions were 303 identified using a spatial overlay, which although it is a very conservative approach (Harvey et 304 al., 2017), it can be useful to detect areas where to focus conservation efforts (Tolimieri et al., 305 2015).

307 Acknowledgments

308 This is a contribution of the Gulf of Mexico Research Consortium (CIGoM). We acknowledge 309 PEMEX's specific request to the Hydrocarbon Fund to address the environmental effects of oil 310 spills in the Gulf of Mexico. We thank Paloma Ladrón de Guevara, Georgina Castro, and Fernanda 311 Urrutia for helping to obtain and compile the occurrence data; Aimie Moulin and Rigel Zaragoza 
312 for helping to process the environmental layers, and Fabricio Villalobos and Carlos Yañez-Arenas

313 for technical support; Sharon Herzka for key logistic support. We appreciate the suggestions of

314 Ladd Irvine, Jason Roberts and one anonymous reviewer, which greatly improved the manuscript.

315

316 References

317 Aiello-Lammens ME, Boria RA, Radosavljevic A, Vilela B, Anderson RP. 2015. spThin: an R

318 package for spatial thinning of species occurrence records for use in ecological niche models. Ecography 38:541-545. DOI: 10.1111/ecog.01132.

Anderson RP. 2017. When and how should biotic interactions be considered in models of species niches and distributions? Journal of Biogeography 44:8-17. DOI: 10.1111/jbi.12825

Anderson RP, Gonzalez I. 2011. Species-specific tuning increases robustness to sampling bias in models of species distributions: An implementation with Maxent. Ecological Modelling

Arthur FH, Morrison III WR, Morey AC. 2019. Modeling the potential range expansion of larger grain borer, Prostephanus truncatus (Coleoptera: Bostrichidae). Scientific Reports 9: 6862. DOI: $10.1038 / \mathrm{s} 41598-019-42974-5$

Baird RW, Schorr GS, Webster DL, Mahaffy SD, McSweeney DJ, Hanson MB, Andrews RD. 2009. Movements of satellite-tagged Cuvier's and Blainville's beaked whales in Hawaii' i: evidence for an offshore population of Blainville's beaked whales. U.S. Department of Commerce.

Baird RW, Schorr GS, Webster D 1., McSweeney DJ, Hanson MB, Andrews RD. 2010. Movements and habitat use of satellite-tagged false killer whales around the main Hawaiian Islands. Endangered Species Research 10:107-121. DOI: 10.3354/esr00258. 
335

336

337

338

339

340

341

342

343

344

Baird RW, Schorr GS, Webster DL, McSweeney DJ, Hanson MB, Andrews RD. 2011. Movements of two satellite-tagged pygmy killer whales (Feresa attenuata) off the island of Hawai'i. Marine Mammal Science 27:E332-E337. DOI: 10.1111/j.17487692.2010.00458.x.

Baird RW, Webster DL, Aschettino JM, Verbeck D, Mahaffy SD. 2012. Odontocete movements off the island of Kau'I: Results of satellite tagging and photo-identification efforts in January 2012. Cascadia Research Collective.

Baumgartner MF. 1997. The distribution of Risso's dolphin (Grampus griseus) with respect to the physiography of the northern Gulf of Mexico. Marine Mammal Science 13:614-638.

Baumgartner MF, Mullin KD, May LN, Leming TD. 2001. Cetacean habitats in the northern Gulf of Mexico. Fishery Bulletin 99:219-239.

Bearzi M. 2005. Dolphin sympatric ecology. Marine Biology Research 1:165-175. DOI: $10.1080 / 17451000510019132$.

Biggs DC. 1992. Nutrients, plankton, and productivity in a warm-core ring in the western Gulf of Mexico. Journal of Geophysical Research: Oceans 97:2143-2154.

Biggs DC, Leben RR, Ortega-Ortiz JG. 2000. Ship and satellite studies of mesoscale circulation and sperm whale habitats in the northeast Gulf of Mexico during GulfCet II. Gulf of Mexico Science 18:15-22.

Boria RA, Olson LE, Goodman SM, Anderson RP. 2014. Spatial filtering to reduce sampling bias can improve the performance of ecological niche models. Ecological Modelling 275:73-77. DOI: 10.1016/j.ecolmodel.2013.12.012.

Bouma AH, Roberts HH. 1990. Northern Gulf of Mexico continental slope. Geo-Marine Letters 10:177-181. DOI: 10.1007/BF02431064. 
358

359

360

361

362

363

364

365

366

367

368

369

370

371

372

373

374

375

376

377

378

379

380

CONABIO (Comisión Nacional para el Conocimiento y Uso de la Biodiversidad). 2016. Sistema Nacional de Información sobre Biodiversidad de México. http://www.snib.mx/ (accessed on 1 April 2016)

Cruz-Cárdenas G, López-Mata L, Villaseñor JL, Ortiz E. 2014. Potential species distribution modeling and the use of principal component analysis as predictor variables. Revista Mexicana de Biodiversidad 85:189-199. DOI: 10.7550/rmb.36723.

Davis RW, Fargion GS, May N, Leming TD, Baumgartner M, Evans WE, Hansen LJ, Mullin K. 1998. Physical habitat of cetaceans along the continental slope in the north-central and western Gulf of Mexico. Marine Mammal Science 14:490-507.

Davis RW, Ortega-Ortiz JG, Ribic CA, Evans WE, Biggs DC, Ressler PH, Cady RB, Leben RR, Mullin KD, Würsig B. 2002. Cetacean habitat in the northern oceanic Gulf of Mexico. Deep Sea Research Part I: Oceanographic Research Papers 49:121-142.

Davis RW, Worthy GAJ, Würsig B, Lynn SK, Townsend FI. 1996. Diving behavior and at-sea movements of an Atlantic spotted dolphin in the Gulf of Mexico. Marine Mammal Science 12:569-581. DOI: 10.1111/j.1748-7692.1996.tb00069.x.

De Lanza Espino G, Gómez-Rojas JC. 2004. Physical and chemical characteristics of the Gulf of Mexico. In: Pisanty I, Ezcurra E, Whiters K, Nipper M eds. Environmental analysis of the Gulf of Mexico. México, D.F. Harte Research Institute for Gulf of Mexico Studies Special Publication Series $N^{\circ} 1,41-61$.

Del Castillo CE, Coble PG, Conmy RN, Müller-Karger FE, Vanderbloemen L, Vargo GA. 2001. Multispectral in situ measurements of organic matter and chlorophyll fluorescence in seawater: documenting the intrusion of the Mississippi River plume in the West Florida Shelf. Limnology and Oceanography 46:1836-1843. DOI: 10.4319/lo.2001.46.7.1836. 
381 Dormann CF, Elith J, Bacher S, Buchmann C, Carl G, Carré G, Marquéz JRG, Gruber B,

382

383

384

385

386

387

388

389

390

391

392

393

394

395

396

397

398

399

400

401

402

403

Lafourcade B, Leitão PJ, Münkemüller T, McClean C, Osborne PE, Reineking B, Schröder B, Skidmore AK, Zurell D, Lautenbach S. 2013. Collinearity: a review of methods to deal with it and a simulation study evaluating their performance. Ecography 36:27-46. DOI: 10.1111/j.1600-0587.2012.07348.x.

Dormann CF, Schymanski SJ, Cabral J, Chuine I, Graham C, Hartig F, Kearney M, Morin X, Römermann C, Schröder B. 2012. Correlation and process in species distribution models: bridging a dichotomy. Journal of Biogeography 39:2119-2131.

Elith J, Graham CH, Anderson RP, Dudík M, Ferrier S, Guisan A, Hijmans RJ, Huettmann F, Leathwick JR, Lehmann A, Li J, Lohmann LG, Loiselle BA, Manion G, Moritz C, Nakamura M, Nakazawa Y, McC. Overton J, Peterson AT, Phillips SJ, Richarson K, Scachetti-Pereira R, Schapire RE, Soberón J, Williams S, Wisz MS, Zimmermann NE. 2006. Novel methods improve prediction of species' distributions from occurrence data. Ecography 29:129-151.

Fernandez M, Yesson C, Gannier A, Miller PI, Azevedo JMN. 2018. A matter of timing: how temporal scale selection influences cetacean ecological niche modelling. Marine Ecology Progress Series 595:217-231. DOI: 10.3354/meps12551.

Franklin J. 2010. Mapping species distribution: spatial inference and prediction. Cambridge University Press.

Forcada J. 2018. Distribution. In: Würsig B, Thewissen JGM, Kovacs KM eds. Encyclopedia of Marine Mammals. Elsevier, 259-262. DOI: 10.1016/B978-0-12-804327-1.00106-0.

Gannier A. 1999. Diel variations of the striped dolphin distribution o $\square$ the French Riviera (Northwestern Mediterranean Sea). Aquatic Mammals 25:123-134.

Peer] reviewing PDF | (2020:07:50756:2:0:NEW 24 Dec 2020) 
404 Griffin RB, Griffin NJ. 2003. Distribution, habitat partitioning, and abundance of Atlantic 405 spotted dolphins, bottlenose dolphins, and loggerhead sea turtles on the eastern Gulf of Mexico continental shelf. Gulf of Mexico Science 21:23-34.

407

408

409

410

411

412

413

414

415

416

417

418

419

420

421

422

423

424

425

Guisan A, Zimmermann NE. 2000. Predictive habitat distribution models in ecology. Ecological Modelling 135:147-186.

Halpin PN, Read AJ, Best BD, Hyrenbach KD, Fujioka E, Coyne MS, Crowder LB, Freeman SA, Spoerri C. 2006. OBIS-SEAMAP: developing a biogeographic research data commons for the ecological studies of marine mammals, seabirds, and sea turtles. Marine Ecology Progress Series 316:239-246. DOI: 10.3354/meps316239.

Harvey GKA, Nelson TA, Fox CH, Paquet PC. 2017. Quantifying marine mammal hotspots in British Columbia, Canada. Ecosphere 8: e01884. DOI: 10.1002/ecs2.1884

Hijmans RJ, van Etten J, Mattiuzzi M, Sumner M, Greenberg J, Lamigueiro O, Bevan A, Racine E, Shortridge A. 2013. Raster package in R.

IOC (Intergovernmental Oceanographic Commission), IHO (International Hydrographic Organization). 2018. GEBCO Digital Atlas published by the British Oceanographic Data Centre on behalf of IOC and IHO. http://www.gebco.net/ (accessed 1 March 2018)

Irvine AB, Scott MD, Wells RS, Kaufmann JH. 1981. Movements and activities of the Atlantic bottlenose dolphin, Tursiops truncatus, near Sarasota, Florida. Fishery Bulletin 79:671688.

Karnauskas M, Schirripa MJ, Kelble CR, Cook GS, Craig JK. 2013. Ecosystem Status Report for the Gulf of Mexico. U.S. Department of Commerce, National Oceanic and Atmospheric Administration, National Marine Fisheries Service, Southeast Fisheries Science Center. 
426 Kaschner K, Tittensor DP, Ready J, Gerrodette T, Worm B. 2011. Current and Future Patterns of 427 Global Marine Mammal Biodiversity. PLOS ONE 6:e19653. DOI:

428 10.1371/journal.pone.0019653.

429

430

431

432

433

434

435

436

437

438

439

440

441

442

443

444

445

446

447 Biology: An Annual Review 26:553-568.

Kenney RD, Scott GP, Thompson TJ, Winn HE. 1997. Estimates of prey consumption and trophic impacts of cetaceans in the USA northeast continental shelf ecosystem. Journal of Northwest Atlantic Fishery Science 22:155-171.

Kramer-Schadt S, Niedballa J, Pilgrim JD, Schröder B, Lindenborn J, Reinfelder V, Stillfried M, Heckmann I, Scharf AK, Augeri DM, Cheyne SM, Hearn AJ, Ross J, Macdonald DW, Mathai J, Eaton J, Marshall AJ, Semiadi G, Rustam R, Bernard H, Alfred R, Samejima H, Duckworth JW, Breitenmoser-Wuersten C, Belant JL, Hofer H, Wilting A. 2013. The importance of correcting for sampling bias in MaxEnt species distribution models. Diversity and Distributions 19:1366-1379. DOI: 10.1111/ddi.12096

Lohrenz SE, Fahnenstiel GL, Redalje DG, Lang GA, Chen X, Dagg MJ. 1997. Variations in primary production of northern Gulf of Mexico continental shelf waters linked to nutrient inputs from the Mississippi River. Marine Ecology Progress Series 155: 45 - 54. DOI:10.3354/meps 155045

Lohrenz SE, Wiesenburg DA, Arnone RA, Chen X. 1999. What controls primary production in the Gulf of Mexico? In: Kumpf H, Steidinger K, Sherman K eds. The Gulf of Mexico Large Marine Ecosystem: Assessment, Sustainability and Magnament. Malden, M.A.: Blackwell Science, 151-170. 
448 MacLeod CD. 2009. Global climate change, range changes and potential implications for the 449 conservation of marine cetaceans: a review and synthesis. Endangered Species Research

450 $7: 125-136$.

451

452

453

454

455

456

457

458

459

460

461

462

463

464

465

466

467

468

469

Mannocci L, Roberts JJ, Miller DL, Halpin PN. 2017 Extrapolating cetacean densities to quantitatively assess human impacts on populations in the high seas. Conservation Biology 31: 601-614. DOI: 10.1111/cobi.12856.

Martínez-López B, Zavala-Hidalgo J. 2009. Seasonal and interannual variability of cross-shelf transports of chlorophyll in the Gulf of Mexico. Journal of Marine Systems 77:1-20. DOI: 10.1016/j.jmarsys.2008.10.002.

Martínez-Serrano I, Serrano A, Heckel G, Schramm Y. 2011. Distribution and home range of bottlenose dolphins (Tursiops truncatus) off Veracruz, Mexico. Ciencias Marinas $37: 379-392$.

Maze-Foley K, Mullin KD. 2006. Cetaceans of the oceanic northern Gulf of Mexico: distributions, group sizes and interspecific associations. Journal of Cetacean Research and Management 8:203-213.

McAlpine DF. 2018. Pygmy and dwarf sperm whales: Kogia breviceps and K. sima. In: Encyclopedia of marine mammals. Elsevier, 786-788.

Merow C, Smith MJ, Edwards Jr, TC, Guisan A, McMahon SM, Normand S, Thuiller W, Wüest RO, Zimmermann NE, Elith J. 2014. What do we gain from simplicity versus complexity in species distribution models? Ecography 37:1267-1281. DOI: 10.1111/ecog.00845

Monreal-Gómez MA, Salas-de León DA, Velasco-Méndoza H. 2004. The hydrodynamics of the Gulf of Mexico. In: Pisanty I, Ezcurra E, Whiters K, Nipper M eds. Environmental 
analysis of the Gulf of Mexico. México, D.F.: Harte Research Institute for Gulf of Mexico Studies Special Publication Series N²1, 2-17.

472

473

474

475

476

477

478

479

480

481

482

483

484

485

486

487

488

489

490

491

492

Moors-Murphy HB. 2014. Submarine canyons as important habitat for cetaceans, with special reference to the Gully: A review. Deep Sea Research Part II: Topical Studies in Oceanography 104:6-19. DOI: 10.1016/j.dsr2.2013.12.016.

Morey SL, Schroeder WW, O'Brien JJ, Zavala-Hidalgo J. 2003. The annual cycle of riverine influence in the eastern Gulf of Mexico basin. Geophysical Research Letters 30. DOI: 10.1029/2003GL017348.

Muller-Karger FE, Smith JP, Werner S, Chen R, Roffer M, Liu Y, Muhling B, Lindo-Atichati D, Lamkin J, Cerdeira-Estrada S, Enfield DB. 2015. Natural variability of surface oceanographic conditions in the offshore Gulf of Mexico. Progress in Oceanography 134:54-76. DOI: 10.1016/j.pocean.2014.12.007.

Mullin KD, Fulling GL. 2004. Abundance of cetaceans in the oceanic northern Gulf of Mexico, 1996-2001. Marine Mammal Science 20:787-807.

Mullin KD, Lohoefener RR, Hoggard W, Roden CL, Rogers CM. 1990. Abundance of bottlenose dolphins, Tursiops truncatus, in the coastal Gulf of Mexico. Northeast Gulf Science 11:113-122.

Muscarella R, Galante PJ, Soley-Guardia M, Boria RA, Kass JM, Uriarte M, Anderson RP. 2014. ENM eval: An R package for conducting spatially independent evaluations and estimating optimal model complexity for Maxent ecological niche models. Methods in Ecology and Evolution 5:1198-1205.

Muscarella R, Galante P, Soley-Guardia M, Boria R, Kass J, Uriarte M, Anderson R. 2016. Package "ENMeval: Automated runs and evaluations of ecological niche models". 
493 NASA Goddard Space Flight Center, Ocean Ecology Laboratory, Ocean Biology Processing 494 Group. 2018. Moderate-resolution Imaging Spectroradiometer (MODIS) Aqua. NASA

495 496

497

498

499

500

501

502

503

504

505

506

507

508

509

510

511

512

513

514

OB.DAAC, Greenbelt, MD. https://oceancolor.gsfc.nasa.gov/13/ (accessed 15 August 2018).

O'Hern JE, Biggs DC. 2009. Sperm whale (Physeter macrocephalus) habitat in the Gulf of Mexico: satellite observed ocean color and altimetry applied to small-scale variability in distribution. Aquatic Mammals 35:358-366. DOI: 10.1578/AM.35.3.2009.358.

Olson PA. 2018. Pilot Whales: Globicephala melas and G. macrorhynchus. In: Würsig B, Thewissen JGM, Kovacs KM eds. Encyclopedia of Marine Mammals (Third Edition). Academic Press, 701-705. DOI: 10.1016/B978-0-12-804327-1.00194-1.

Pace DS, Arcangeli A, Mussi B, Vivaldi C, Ledon C, Lagorio S, Giacomini G, Pavan G, Ardizzone G. 2018. Habitat suitability modeling in different sperm whale social groups: sperm whale habitat suitability modeling. The Journal of Wildlife Management 82:10621073. DOI: $10.1002 /$ jwmg.21453.

Perrin WF. 2018. Spinner dolphin: Stenella longirostris. In: Würsig B, Thewissen JGM, Kovacs KM eds. Encyclopedia of Marine Mammals (Third Edition). Academic Press, 925-928. DOI: 10.1016/B978-0-12-804327-1.00243-0.

Peterson AT, Soberón J. 2012. Species distribution modeling and ecological niche modeling: getting the concepts right. Natureza \& Conservação 10:102-107. DOI: 10.4322/natcon.2012.019.

Peterson AT, Soberón J, Pearson RG, Anderson RP, Martínez-Meyer E, Nakamura M, Araújo MB. 2011. Ecological niches and geographic distributions. Princeton University Press. 
515 Phillips SJ, Anderson RP, Dudík M, Schapire RE, Blair ME. 2017. Opening the black box: an

516 open-source release of Maxent. Ecography 40:887-893. DOI: 10.1111/ecog.03049.

517 Phillips SJ, Anderson RP, Schapire RE. 2006. Maximum entropy modeling of species

518 geographic distributions. Ecological Modelling 190:231-259. DOI:

$519 \quad 10.1016 /$ j.ecolmodel.2005.03.026.

520 Praca E, Gannier A, Das K, Laran S. 2009. Modelling the habitat suitability of cetaceans:

521 Example of the sperm whale in the northwestern Mediterranean Sea. Deep Sea Research

522 Part I: Oceanographic Research Papers 56:648-657. DOI: 10.1016/j.dsr.2008.11.001.

523 R Core Team. 2019. R: A language and environment for statistical computing.

524 Radosavljevic A, Anderson RP. 2014. Making better Maxent models of species distributions:

525 complexity, overfitting and evaluation. Journal of Biogeography 41:629-643. DOI:

$526 \quad 10.1111 /$ jbi.12227.

527 Raes N, Aguirre-Gutiérrez J. 2018. Modeling framework to estimate and project species

528 distributions space and time. In: Hoorn C, Perrigo A, Antonelli A eds. Mountains,

529 Climate and Biodiversity. Wiley Blackwell, 309-320.

530 Ramírez-León MR, García-Aguilar MC, Aguayo-Lobo A, Fuentes-Allen I, Sosa-Nishizaki O.

531 2020. What do we know about cetaceans in the Mexican waters of the Gulf of Mexico? A

532 review. Aquatic Mammals 46:623-632. DOI 10.1578/AM.46.6.2020.623

533 Roberts JJ, Best BD, Mannocci L, Fujioka E, Halpin PN, Palka DL, Garrison LP, Mullin KD,

534 Cole TVN, Khan CB, McLellan WA, Pabst DA, Lockhart GG. 2016. Habitat-based

535 cetacean density models for the U.S. Atlantic and Gulf of Mexico. Scientific Reports 6.

$536 \quad$ DOI: $10.1038 /$ srep22615. 
537 Salmerón-García O, Zavala-Hidalgo J, Mateos-Jasso A, Romero-Centeno R. 2011.

538 Regionalization of the Gulf of Mexico from space-time chlorophyll-a concentration

539 variability. Ocean Dynamics 61:439-448. DOI: 10.1007/s10236-010-0368-1.

540 Shepard AN, Valentine JF, D’Elia CF, Yoskowitz DW, Dismukes DE. 2013. Economic impact of Gulf of Mexico ecosystem goods and services and integration into restoration decision-making. Gulf of Mexico Science 31:2. DOI: 10.18785/goms.3101.02

Schick RS, Halpin PN, Read AJ, Urban DL, Best BD, Good CP, Roberts JJ, LaBrecque EA, Dunn C, Garrison LP, Hyrenbach KD, McLellan WA, Pabst DA, Palka DL, Stevick P. 2011. Community structure in pelagic marine mammals at large spatial scales. Marine Ecology Progress Series 434:165-181. DOI: 10.3354/meps09183.

547

548

549

550

551

552

553

554

555

556

557

558

Scott MD, Chivers SJ. 2009. Movements and diving behavior of pelagic spotted dolphins. Marine Mammal Science 25:137-160. DOI: 10.1111/j.1748-7692.2008.00241.x.

Soberón J, Peterson AT. 2005. Interpretation of models of fundamental ecological niches and species' distributional areas. Biodiversity Informatics 2:1-10.

Soldevilla MS, Hildebrand JA, Frasier KE, Aichinger-Dias L, Martinez A, Mullin KD, Rosel PE, Garrison LP. 2017. Spatial distribution and dive behavior of Gulf of Mexico Bryde's whales: potential risk of vessel strikes and fisheries interactions. Endangered Species Research 32:533-550. DOI: 10.3354/esr00834.

Spalding MD, Fox HE, Allen GR, Davidson N, Ferdaña ZA, Finlayson M, Halpern BS, Jorge MA, Lombana A, Lourie SA, Martin KD, McManus E, Molnar J, Recchia CA, Robertson J. 2007. Marine ecoregions of the world: A bioregionalization of coastal and shelf areas. BioScience 57:573-583. DOI: 10.1641/B570707. 
559 Tolimieri N, Shelton AO, Feist BE, Simon V. 2015. Can we increase our confidence about the 560 locations of biodiversity 'hotspots' by using multiple diversity indices? Ecosphere 6:290.

561 DOI: $10.1890 / \mathrm{ES} 14-00363.1$.

562 Toner M. 2003. Chlorophyll dispersal by eddy-eddy interactions in the Gulf of Mexico. Journal 563 of Geophysical Research 108:3105. DOI: 10.1029/2002JC001499.

564 565

566

567

568

569

570

571

572

573

574

575

576

577

578

579

580

581

Varela S, Anderson RP, García-Valdés R, Fernández-González F. 2014. Environmental filters reduce the effects of sampling bias and improve predictions of ecological niche models. Ecography 37:1084-1091. DOI: 10.1111/j.1600-0587.2013.00441.x.

Wells RS, Early GA, Gannon JG, Lingenfelser RG, Sweeney P. 2008. Tagging and tracking of Rough-toothed Dolphins (Steno bredanensis) from the March 2005 mass stranding in the Florida Keys. U.S. Department of Commerce, National Oceanic and Atmospheric Administration, National Marine Fisheries Service, Southeast Fisheries Science Center.

Wells RS, Manire CA, Byrd L, Smith DR, Gannon JG, Fauquier D, Mullin KD. 2009. Movements and dive patterns of a rehabilitated Risso's dolphin, Grampus griseus, in the Gulf of Mexico and Atlantic Ocean. Marine Mammal Science 25:420-429. DOI: 10.1111/j.1748-7692.2008.00251.x.

Whitehead H. 2018. Sperm whale: Physeter macrocephalus. In: Würsig B, Thewissen JGM, Kovacs KM eds. Encyclopedia of Marine Mammals (Third Edition). Academic Press, 919-925. DOI: 10.1016/B978-0-12-804327-1.00242-9.

Wisz MS, Hijmans RJ, Li J, Peterson AT, Graham CH, Guisan A, NCEAS Predicting Species Distributions Working Group †. 2008. Effects of sample size on the performance of species distribution models. Diversity and Distributions 14:763-773. DOI: 10.1111/j.1472-4642.2008.00482.x. 
582 Würsig B. 2017. Marine Mammals of the Gulf of Mexico. In: Ward CH ed. Habitats and Biota 583 of the Gulf of Mexico: Before the Deepwater Horizon oil spill, Volume 2: Fish resources, fisheries, sea turtles, avian resources, marine mammals, diseases and mortalities. New York, NY: Springer Open, 1489-1588.

586 Yen PPW, Sydeman WJ, Hyrenbach KD. 2004. Marine birds and cetacean associations with 587 bathymetric habitats and shallow-water topographies: implications for trophic transfer 588 and conservation. Journal of Marine Systems 50: 79-99. DOI: 10.1016/j.jmarsys.2003.09.015.

590 Zavala-Hidalgo J, Morey SL, O'Brien JJ. 2003. Seasonal circulation on the western shelf of the 591 Gulf of Mexico using a high-resolution numerical model. Journal of Geophysical Research 108. DOI: 10.1029/2003JC001879. 


\section{Table $\mathbf{1}$ (on next page)}

Georeferenced records for 16 odontocetes from the Gulf of Mexico

Total number of georeferenced sightings of 16 odontocetes in the Gulf of Mexico, period of the presence data, filtering distance (average daily displacement in $\mathrm{km}$ ), and number of sightings used in modeling (sample size). Modeled species are marked with *. 
1 Table 1. Total number of georeferenced sightings of 16 odontocetes in the Gulf of Mexico, period of the presence data, filtering

2 distance (average daily displacement in $\mathrm{km}$ ), and number of sightings used in modeling (sample size). Modeled species are marked

3 with *.

\begin{tabular}{|c|c|c|c|c|c|}
\hline Scientific name & Common name & Period & Total sightings & $\begin{array}{l}\text { Filtering } \\
\text { distance }\end{array}$ & $\begin{array}{c}\text { Used sightings } \\
\text { (n) }\end{array}$ \\
\hline Physeter macrocephalus* & Sperm whale & $1978-2017$ & 810 & $90^{1}$ & 70 \\
\hline Kogia breviceps & Pygmy sperm whale & $1992-2011$ & 51 & $75^{2}$ & 17 \\
\hline Kogia sima* & Dwarf sperm whale & $1990-2011$ & 319 & $75^{2}$ & 37 \\
\hline Ziphius cavirostris* & Cuvier's beaked whale & $1990-2017$ & 88 & $25^{3}$ & 39 \\
\hline Feresa attenuata & Pygmy killer whale & $1990-2008$ & 24 & $70^{4}$ & 16 \\
\hline Peponocephala electra & Melon-headed whale & $1992-2011$ & 70 & $70^{5}$ & 25 \\
\hline Pseudorca crassidens & False killer whale & $1986-2017$ & 96 & $70^{6}$ & 25 \\
\hline Globicephala macrorhynchus* & Short-finned pilot whale & $1984-2017$ & 200 & $80^{7}$ & 61 \\
\hline Steno bredanensis* & Rough-toothed dolphin & $1983-2017$ & 90 & $90^{8}$ & 37 \\
\hline Grampus griseus* & Risso's dolphin & $1990-2017$ & 330 & $80^{9}$ & 54 \\
\hline Stenella frontalis* & Atlantic spotted dolphin & $1979-2015$ & 1,557 & $70^{10}$ & 128 \\
\hline
\end{tabular}


5 Table 1. Continuation.

\begin{tabular}{|c|c|c|c|c|c|}
\hline Scientific name & Common name & Period & Total sightings & $\begin{array}{l}\text { Filtering } \\
\text { distance }\end{array}$ & $\begin{array}{c}\text { Used sightings } \\
\text { (n) }\end{array}$ \\
\hline Stenella attenuata* & Pantropical spotted dolphin & $1983-2012$ & 800 & $90^{11}$ & 93 \\
\hline Stenella coeruleoalba* & Striped dolphin & $1992-2005$ & 76 & $90^{12}$ & 35 \\
\hline Stenella longirostris* & Spinner dolphin & $1983-2012$ & 126 & $80^{13}$ & 41 \\
\hline Stenella clymene* & Clymene dolphin & $1990-1998$ & 108 & $70^{12}$ & 37 \\
\hline Tursiops truncatus* & Bottlenose dolphin & $1971-2017$ & 3,778 & $35^{14}$ & 305 \\
\hline
\end{tabular}

6 Sources: ${ }^{1}$ Whitehead (2018), ${ }^{2}$ McAlpine, (2018), ${ }^{3}$ Baird et al. (2009), ${ }^{4}$ Baird et al. (2011), ${ }^{5}$ Baird et al. (2012), ${ }^{6}$ Baird et al. (2010),

$7 \quad{ }^{7}$ Olson (2018), ${ }^{8}$ Wells et al. (2008), ${ }^{9}$ Wells et al. (2009), ${ }^{10}$ Davis et al. (1996), ${ }^{11}$ Scott \& Chivers (2009), ${ }^{12}$ Gannier (1999), ${ }^{13}$ Perrin 8 (2018), ${ }^{14}$ Irvine et al. (1981) 


\section{Table 2 (on next page)}

Statistics of each model and contribution percentages of each environmental predictor

Values of the area under the receiver operator curve (AUC) and of the 10-percentile training omission rate $\left(\mathrm{OR}_{10}\right)$, and percent of contribution of the environmental predictors in each model. Environmental predictors: $\mathrm{SST}_{\mathrm{m}}=$ mean sea surface temperature, $\mathrm{SST}_{\min }=$ minimum sea surface temperature, $\mathrm{SST}_{\max }=$ maximum sea surface temperature, $\mathrm{Chl}-\mathrm{a}_{\mathrm{m}}=$ mean chlorophyll-a concentration, $\mathrm{Chl}-a_{\min }=$ minimum chlorophyll-a concentration, $\mathrm{Chl}-\mathrm{a}_{\max }=$ maximum chlorophyll-a concentration, $D=$ depth, $S=$ slope, $D_{200}=$ distance to the $200-\mathrm{m}$ isobath. 
1 Table 2. Values of the area under the receiver operator curve (AUC) and of the 10-percentile training omission rate $\left(\mathrm{OR}_{10}\right)$, and

2 percent of contribution of the environmental predictors in each model. Environmental predictors: $\mathrm{SST}_{\mathrm{m}}=$ mean sea surface

3 temperature, $\mathrm{SST}_{\min }=$ minimum sea surface temperature, $\mathrm{SST}_{\max }=$ maximum sea surface temperature, Chl- $a_{\mathrm{m}}=$ mean chlorophyll- $a$

4 concentration, Chl- $a_{\min }=$ minimum chlorophyll- $a$ concentration, Chl- $a_{\max }=$ maximum chlorophyll- $a$ concentration, $D=\operatorname{depth}, S=$

5 slope, $D_{200}=$ distance to the $200-\mathrm{m}$ isobath.

\begin{tabular}{|c|c|c|c|c|c|c|c|c|c|c|c|}
\hline \multirow[b]{2}{*}{ Species } & \multirow[b]{2}{*}{$\mathbf{A U C}$} & \multirow[b]{2}{*}{ OR } & \multicolumn{9}{|c|}{ Environmental predictors } \\
\hline & & & $\mathrm{SST}_{\mathrm{m}}$ & $\mathbf{S S T}_{\text {min }}$ & $\mathbf{S S T}_{\max }$ & Chl- $a_{\mathrm{m}}$ & Chl- $a_{\min }$ & Chl- $a_{\max }$ & $D$ & $S$ & $D_{200}$ \\
\hline Sperm whale & 0.83 & 0.21 & & 17.34 & & & & 7.23 & 38.25 & 9.47 & 27.71 \\
\hline Dwarf sperm whale & 0.86 & 0.28 & & 45.57 & 14.59 & & & 7.96 & 28.81 & 3.06 & \\
\hline Cuvier's beaked whale & 0.85 & 0.24 & & 35.77 & 1.34 & & & & 41.51 & 4.92 & 16.46 \\
\hline Short-finned pilot whale & 0.83 & 0.18 & & 15.25 & & 5.47 & & & 18.00 & 18.76 & 42.53 \\
\hline Rough-toothed dolphin & 0.83 & 0.13 & & 57.93 & 1.10 & 25.45 & & & & 7.45 & 8.07 \\
\hline Risso's dolphin & 0.87 & 0.27 & & 39.06 & 1.23 & 12.86 & & & 29.60 & 17.25 & \\
\hline Atlantic spotted dolphin & 0.83 & 0.20 & & 6.95 & & 4.33 & & & 74.38 & 1.54 & 12.80 \\
\hline Pantropical spotted & 0.74 & 0.25 & & 24.87 & 7.60 & 24.83 & & & 27.68 & 8.59 & 6.44 \\
\hline
\end{tabular}


7 Table 2. Continuation

Environmental predictors

\begin{tabular}{|c|c|c|c|c|c|c|c|c|c|c|c|}
\hline Specie & $\mathbf{A U C}$ & OR & $\mathbf{S S T}_{\mathbf{m}}$ & $\mathbf{S S T}_{\text {min }}$ & $\mathbf{S S T}_{\max }$ & Chl- $a_{\mathrm{m}}$ & Chl- $a_{\text {min }}$ & Chl- $a_{\max }$ & $D$ & $S$ & $D_{200}$ \\
\hline Striped dolphin & 0.81 & 0.25 & 21.28 & & 13.91 & 37.04 & & & 16.85 & 10.91 & \\
\hline Spinner dolphin & 0.80 & 0.38 & & 8.88 & 4.75 & 28.27 & & & 10.04 & 15.44 & 32.62 \\
\hline Clymene dolphin & 0.88 & 0.16 & 44.88 & & 18.27 & & & 18.37 & & 14.44 & 4.03 \\
\hline Bottlenose dolphin & 0.91 & 0.16 & & 20.18 & 1.07 & 2.91 & & & 75.84 & & \\
\hline
\end{tabular}

8 
Figure 1

Study and modeling area

(A) Geographic extension of the modeling area in the northwestern Atlantic Ocean. (B) Gulf of Mexico and physiographic sub-provinces: 1. West Florida shelf, 2. West Florida slope, 3.

Mississippi-Alabama shelf, 4. Mississippi Canyon, 5. Louisiana-Texas shelf, 6. Louisiana-Texas slope, 7. Rio Grande slope, 8. Tamaulipas-Veracruz shelf, 9. Tamaulipas-Veracruz slope, 10. Bay of Campeche. 11. Bank of Campeche, 12. Yucatan shelf, 13. Campeche terrace, and 14. Sigsbee plain. 

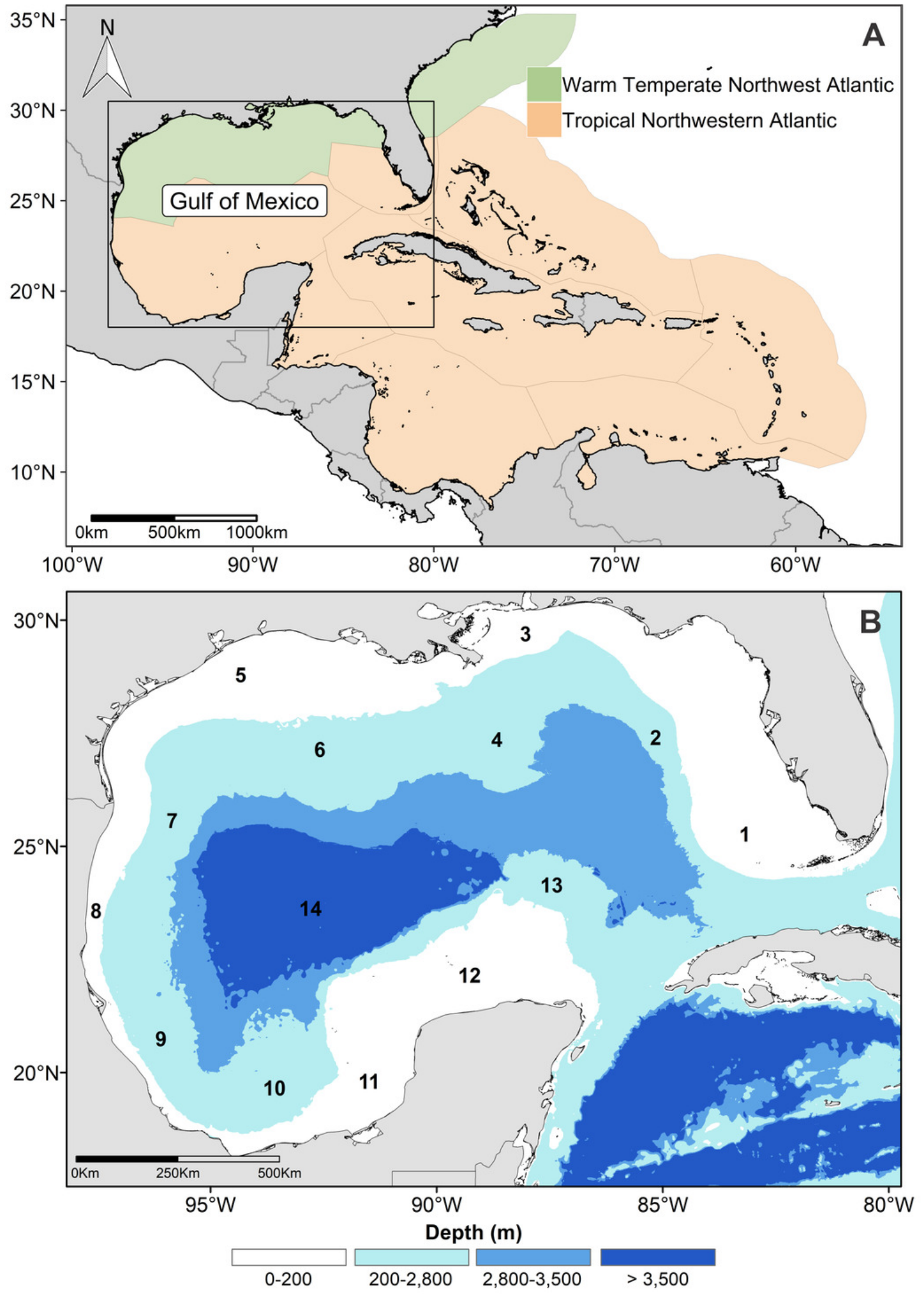
Figure 2

Habitat suitability map

Habitat suitability of (A) sperm whale, (B) dwarf sperm whale, (C) Cuvier's beaked whale, and (D) Short-finned pilot whale. In the scale bar, reds indicates high habitat suitability values ( $\geq$ 0.6) encompassed by the solid line, and light yellow indicates low habitat suitability values.
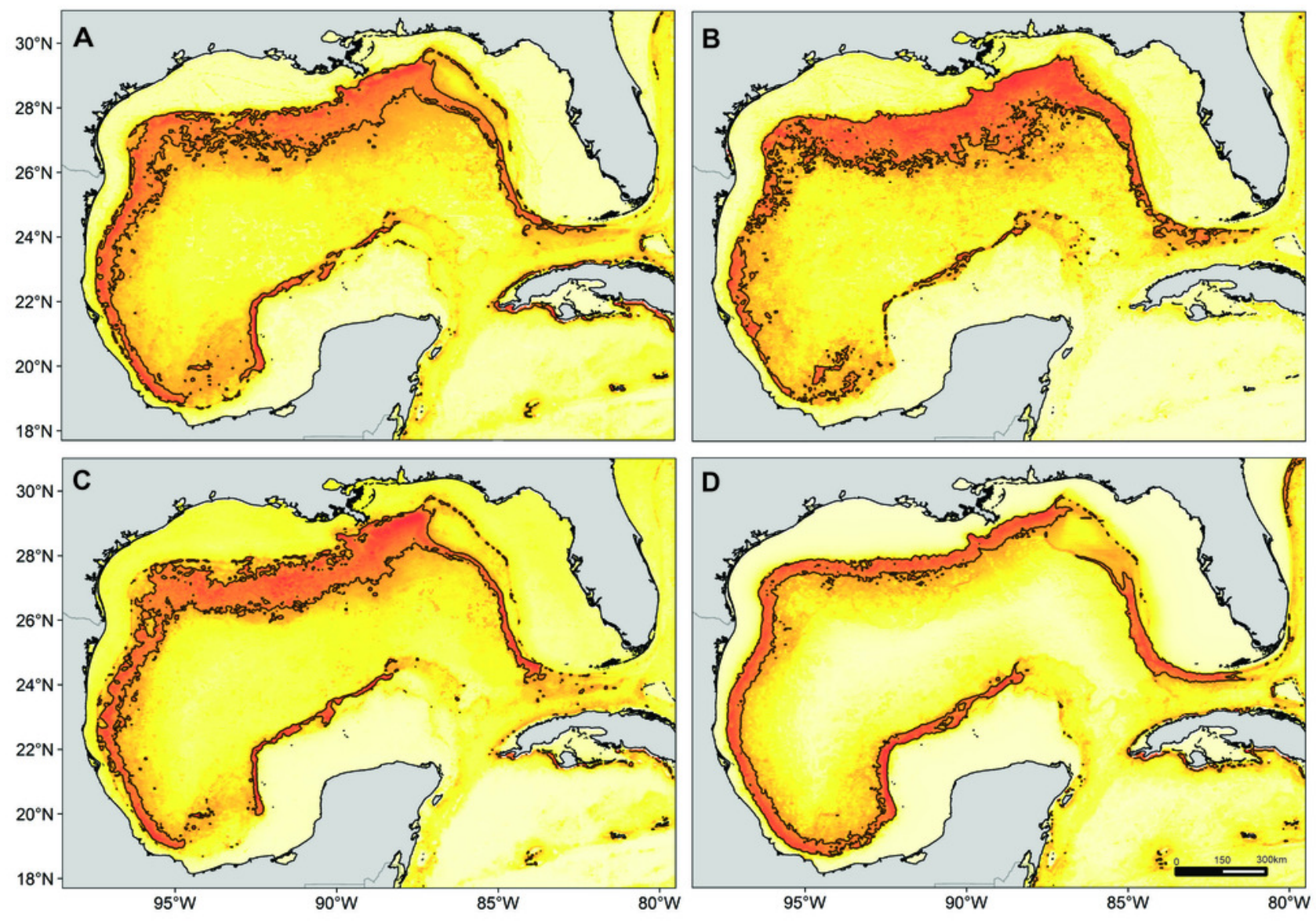

Habitat suitability

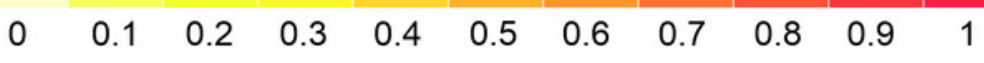




\section{Figure 3}

Habitat suitability map

Habitat suitability of (A) rough-toothed dolphin, (B) Risso's dolphin, (C) Atlantic spotted dolphin, and (D) pantropical spotted dolphin. In the scale bar, reds indicates high habitat suitability values ( $\left.{ }^{3} 0.6\right)$ encompassed by the solid line, and light yellow indicates low habitat suitability values.
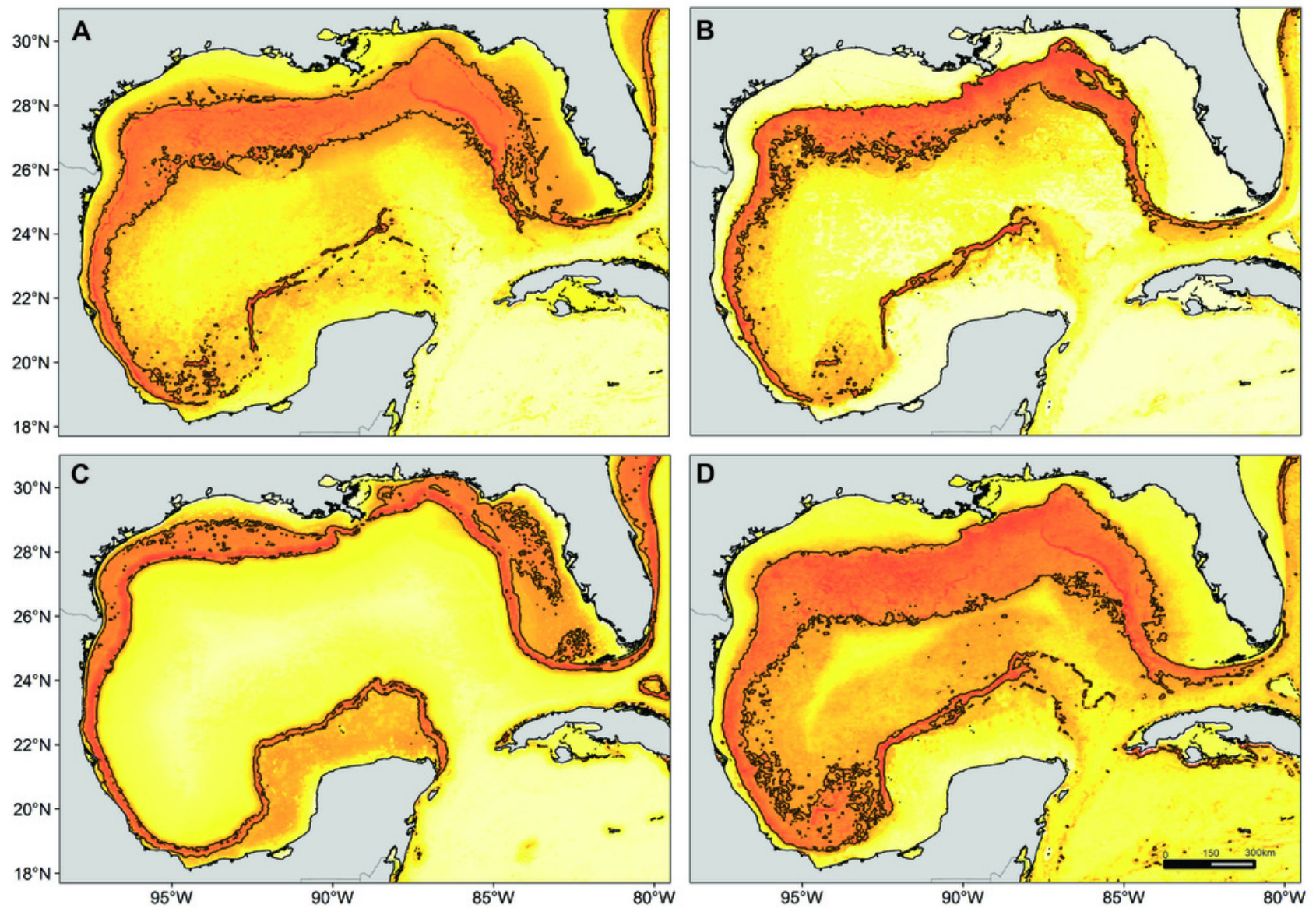

Habitat suitability

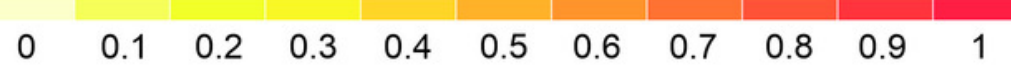


Figure 4

Habitat suitability map

Habitat suitability of (A) striped dolphin, (B) spinner dolphin, (C) clymene dolphin, and D) bottlenose dolphin. In the scale bar, reds indicates high habitat suitability values $(\geq 0.6)$ encompassed by the solid line, and light yellow indicates low habitat suitability values.
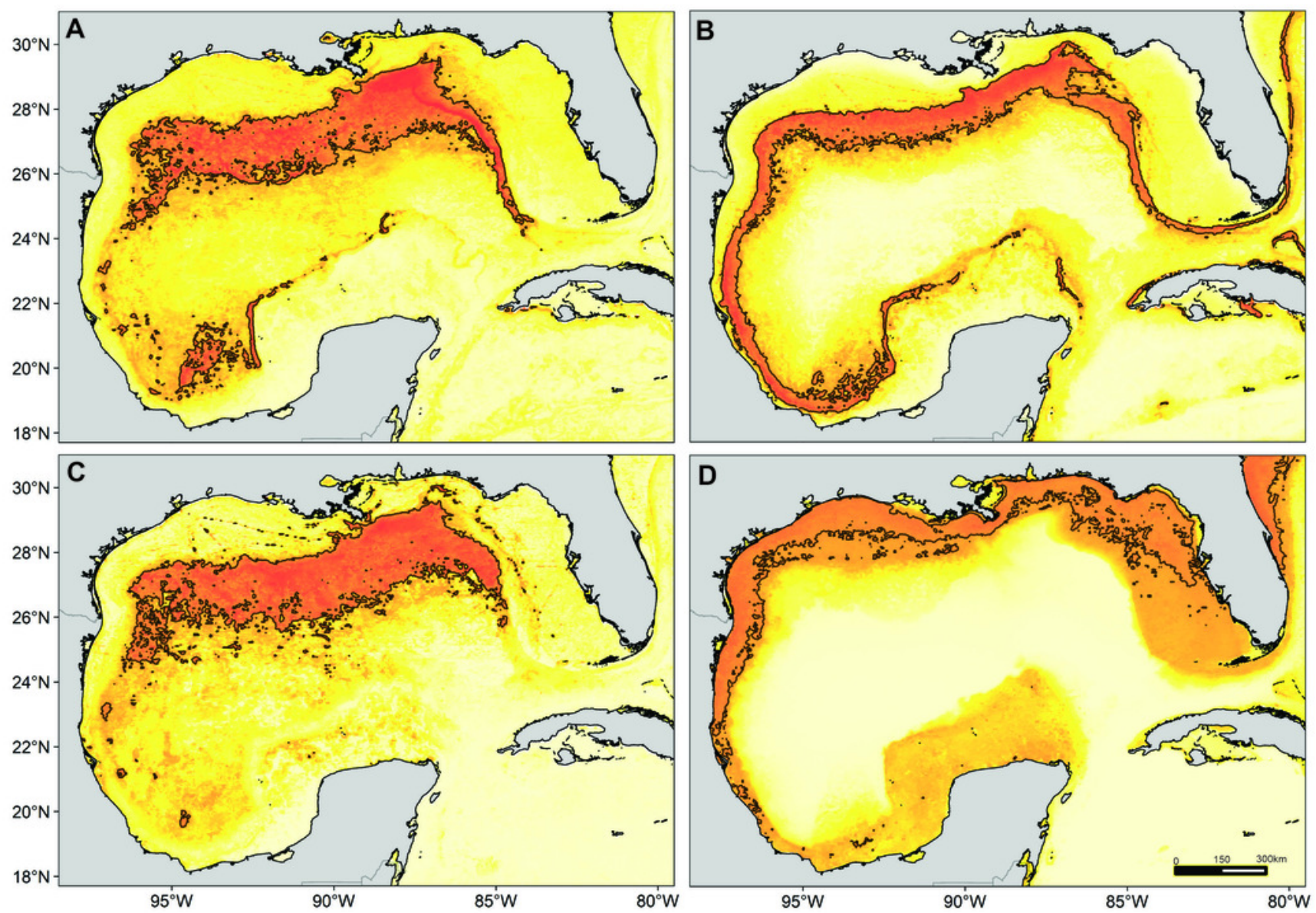

Habitat suitability

$\begin{array}{lllllllllll}0 & 0.1 & 0.2 & 0.3 & 0.4 & 0.5 & 0.6 & 0.7 & 0.8 & 0.9 & 1\end{array}$ 
Figure 5

Suitable regions map

Map of the overlap of the suitable habitat of cetaceans in the Gulf of Mexico. The solid line delimits the highly suitable regions with a high diversity of cetaceans $\geq 7$ species.

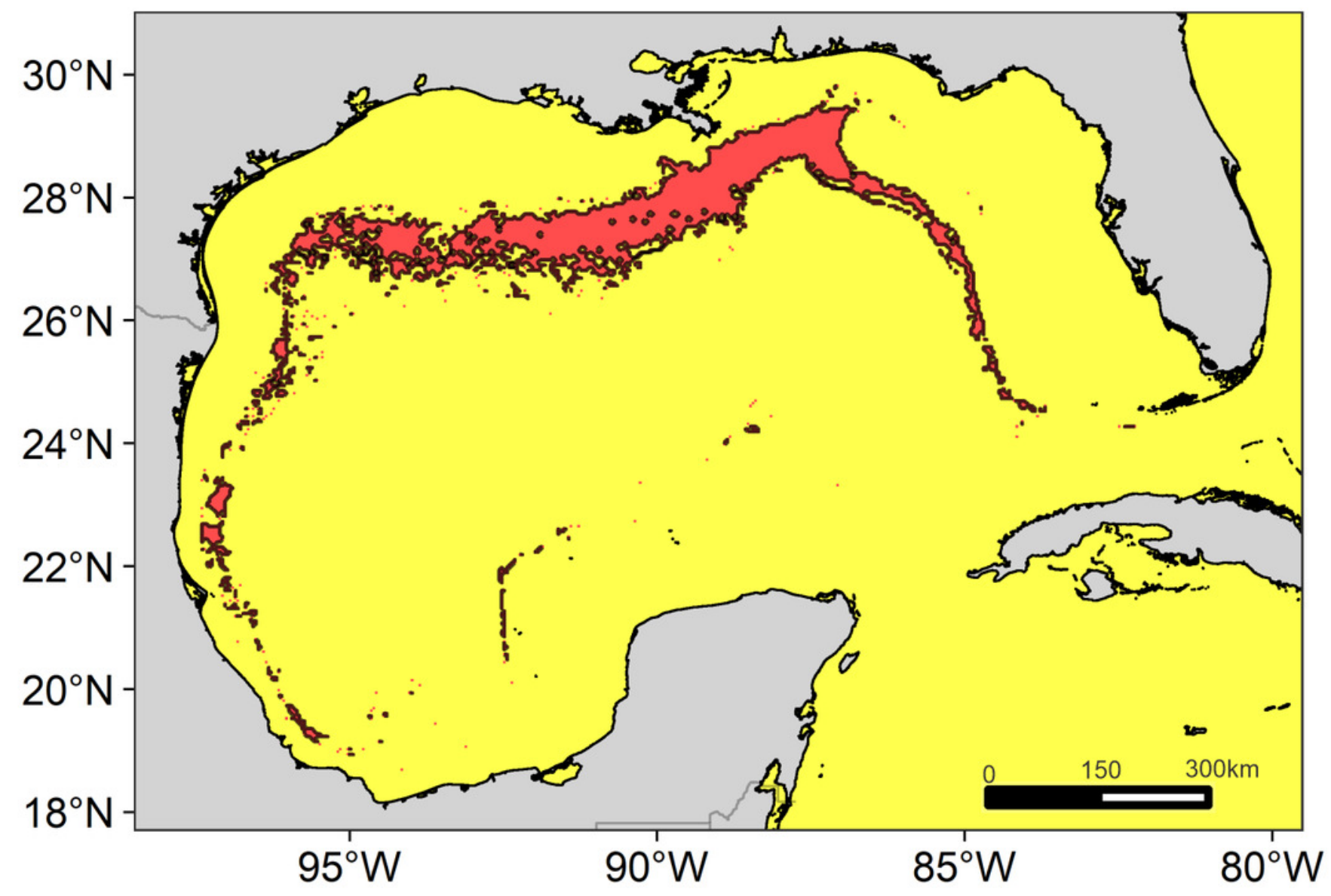

